\title{
Genetics, taxonomy and species complex in sandy beach macrofauna: Reply to Mattos et al. (2018)
}

\author{
Gastón Martínez ${ }^{1,2, *}$, Matías Arim ${ }^{1,2}$, Omar Defeo ${ }^{1,2}$ \\ ${ }^{1}$ Centro Universitario de la Región Este (CURE), Universidad de la República, Ruta 9 y Ruta 15, PC 27000, Rocha, Uruguay \\ ${ }^{2}$ Departamento de Ecología y Evolución, Facultad de Ciencias, Universidad de la República, PC 11400, Montevideo, Uruguay
}

\begin{abstract}
Mattos et al. (2018; Mar Ecol Prog Ser 601:269-271) commented on our evaluation of the abundant-centre hypothesis $(\mathrm{ACH})$ for the distribution of the isopod Excirolana braziliensis (Martínez et al. 2017; Mar Ecol Prog Ser 583:137-148). They stated that our treatment of E. braziliensis as a single species (i.e. ignoring cryptic diversity) invalidates the connection between reported distribution patterns and the $\mathrm{ACH}$. However, from the introduction of the $\mathrm{ACH}$, the set of mechanisms determining distribution patterns has been considered equally important for a single species and for a set of species with similar functional traits, as is the case for the E. braziliensis complex.
\end{abstract}

KEY WORDS: Morphologically related species $\cdot$ Cryptic diversity $\cdot$ Excirolana

Mattos et al. (2018) commented on our article about the distribution of the isopod Excirolana braziliensis on sandy beaches of the Atlantic and Pacific Oceans, and the evaluation of the abundant-centre hypothesis (ACH) for this species (Martínez et al. 2017). They call attention to recent genetic results that identified 13 divergent and geographically restricted lineages along Atlantic and Pacific beaches (Hurtado et al. 2016), where E. braziliensis was formerly considered as a single species (Glynn et al. 1975, Brusca et al. 1995). In this context, Mattos et al. (2018) stated that ignoring this cryptic diversity results in our study not contributing to the general understanding of the $\mathrm{ACH}$. However, unless there is a population rescue effect (Holt \& Keitt 2000), the mechanisms that we considered as determinants of the $\mathrm{ACH}$ are valid for the distribution trend of ecologically closely related species: sister species (Péron \& Altwegg 2015) and species assemblages (Enquist et al. 1995, Ren et al. 2013, Dallas et al. 2017) throughout their geographic range. This is particularly important for the species that comprise the complex grouped as

*Corresponding author: gmartinez@cure.edu.uy
E. braziliensis, which occupy the supralittoral and upper-littoral zones on sandy beaches and have similar biology, life-history traits, and relationships with environmental variables (e.g. Cardoso \& Defeo 2003, 2004, Martínez \& Defeo 2006). As mentioned by Mattos et al. (2018), morphological revisions concluded that E. braziliensis constitutes a single species (Glynn et al. 1975, Brusca et al. 1995) and, therefore, most of the results and interpretations in our article (Martínez et al. 2017) are valid. This is also true if the analysis reflects the geographic trend in a group of very closely morphologically related species, as detailed in Brown (1984), where the theoretical basis of the ACH was developed.

Unfortunately, we were not aware of the results that identified 13 divergent and geographically restricted lineages along Atlantic and Pacific beaches (Hurtado et al. 2016) that had formerly been considered as a single species, i.e. E. braziliensis. However, we explicitly discussed the potential existence of cryptic species in our paper. We are aware that the direct development mode in these ovoviviparous

() The authors 2018. Open Access under Creative Commons by Attribution Licence. Use, distribution and reproduction are unrestricted. Authors and original publication must be credited. 
species tends to isolate populations with low gene flow and connectivity, thus increasing the probability of genetic differentiation between scattered populations over their extensive range (McLachlan \& Defeo 2018). In this context, Sponer \& Lessios (2009), Varela \& Haye (2012), Tourinho et al. (2016) and Hurtado et al. $(2016,2017)$ have also provided critical insight into the genetic diversity and evolutionary history of E. braziliensis and other congeneric species, which could set the basis for a deeper understanding of macroecological distribution patterns in sandy beach macrofauna.

The identification of the existence of cryptic species by Hurtado et al. $(2016,2017)$ represents a significant advance in our understanding of evolutionary processes and macroecological patterns in E. braziliensis, which has been one of the main model species in sandy beach macrofauna. However, morphologically cryptic species could likely respond similarly to environmental conditions when living in sympatry at similar latitudes (Struck et al. 2017). These responses are mostly driven by selection pressures towards very similar morphological forms regardless of the reproductive isolation between them. Therefore, in this context also, our approach is valid to test the $\mathrm{ACH}$. A separate test for the $\mathrm{ACH}$ taking into account divergent lineages, as suggested by Mattos et al. (2018), would represent a valuable evaluation of the sensitivity of macroecological distribution patterns to the existence of cryptic species. However, we think that phylogeographic studies and taxonomic revision of the genus Excirolana need to be completed (see also Hurtado et al. 2016). Even though cryptic species could represent a substantial fraction of biodiversity (including those inhabiting sandy beaches), Struck et al. (2017) recently highlighted that an effort should be made to clearly differentiate taxonomical errors from true cryptic biodiversity. This topic is under debate (Heethoff 2018). In the specific case of E. braziliensis, taxonomic uncertainties still remain. We think that a useful approach to fill these gaps should be to follow an integrative taxonomy framework, combining information from different approaches and disciplines (e.g. geometric morphometrics methods, DNA barcodes, nuclear gene sequences, full mitochondrial genome data) to provide a comprehensive description of species (Zúñiga-Reinoso \& Benítez 2015, Beermann et al. 2018, Eme et al. 2018, Struck et al. 2018). These different approaches, combined with morphological, ecological, and geographical information, will facilitate a rigorous identification of entities within species complexes and therefore a deeper understanding of macroscale patterns in sandy beach populations.

\section{LITERATURE CITED}

Beermann J, Westbury MV, Hofreiter M, Hilgers L, Deister F, Neumann H, Raupach MJ (2018) Cryptic species in a well-known habitat: applying taxonomics to the amphipod genus Epimeria (Crustacea, Peracarida). Sci Rep 8: 6893

Brown JH (1984) On the relationship between distribution and abundance of species. Am Nat 124:255-279

Brusca RC, Wetzer R, France SC (1995) Cirolanidae (Crustacea: Isopoda: Flabellifera) of the Tropical Eastern Pacific. Proc San Diego Soc Nat Hist 30:1-96

* Cardoso RS, Defeo O (2003) Geographical patterns in reproductive biology of the Pan-American sandy beach isopod Excirolana braziliensis. Mar Biol 143:573-581

Cardoso RS, Defeo O (2004) Biogeographic patterns in life history traits of the Pan-American sandy beach isopod Excirolana braziliensis. Estuar Coast Shelf Sci 61: 559-568

*Dallas T, Decker RR, Hastings A (2017) Species are not most abundant in the centre of their geographic range or climatic niche. Ecol Let 20:1526-1533

Eme D, Zagmajster M, Deli T, Fišer C and others (2018) Do cryptic species matter in macroecology? Sequencing European groundwater crustaceans yields smaller ranges but does not challenge biodiversity determinants. Ecography 41:424-436

Enquist BJ, Jordan MA, Brown JH (1995) Connections between ecology, biogeography, and paleobiology: relationship between local abundance and geographic distribution in fossil and recent molluscs. Evol Ecol 9: 586-604

Glynn PW, Dexter DM, Bowman TE (1975) Excirolana braziliensis, a Pan-American sand beach isopod: taxonomic status, zonation and distribution. J Zool 175: 509-521

* Heethoff M (2018) Cryptic species - conceptual or terminological chaos? A response to Struck et al. Trends Ecol Evol 33:310

Holt RD, Keitt TH (2000) Alternative causes for range limits: a metapopulation perspective. Ecol Lett 3:41-47

* Hurtado LA, Mateos M, Mattos G, Liu S, Haye PA, Paiva PC (2016) Multiple transisthmian divergences, extensive cryptic diversity, occasional long-distance dispersal, and biogeographic patterns in a marine coastal isopod with an amphi-American distribution. Ecol Evol 6: 7794-7808

* Hurtado LA, Mateos M, Liu S (2017) Phylogeographic patterns of a lower intertidal isopod in the Gulf of California and the Caribbean and comparison with other intertidal isopods. Ecol Evol 7:346-357

*Martínez G, Defeo O (2006) Reproductive biology of the isopod Excirolana braziliensis at the southern edge of its geographical range. Helgol Mar Res 60:273-280

* Martínez G, Arim M, Defeo O (2017) Distribution of the isopod Excirolana braziliensis on sandy beaches of the Atlantic and Pacific Oceans. Mar Ecol Prog Ser 583: $137-148$

Mattos G, Paiva PC, Mateos M, Haye PA, Hurtado LA (2018) The cost of ignoring cryptic diversity in macroecological studies: Comment on Martínez et al. (2017). Mar Ecol Prog Ser 601:269-271

McLachlan A, Defeo O (2018) The ecology of sandy shores, 3rd edn. Academic Press, London 
Péron G, Altwegg R (2015) The abundant centre syndrome and species distributions: insights from closely related species pairs in southern Africa. Glob Ecol Biogeogr 24: 215-225

Ren H, Condit R, Chen B, Mi X and others (2013) Geographical range and local abundance of tree species in China. PLOS ONE 8:e76374

Sponer R, Lessios HA (2009) Mitochondrial phylogeography of the intertidal isopod Excirolana braziliensis on the two sides of the Isthmus of Panama. Smithson Contrib Mar Sci 38:219-228

Struck TH, Jeffrey L, Feder JL, Bendiksby $M$ and others (2017) Finding evolutionary processes hidden in cryptic species. Trends Ecol Evol 33:153-163

Editorial responsibility: Simonetta Fraschetti, Salento, Italy \& Christine Paetzold, Oldendorf/Luhe, Germany
Struck TH, Jeffrey L, Feder JL, Bendiksby M and others (2018) Cryptic Species - more than terminological chaos: a reply to Heethoff. Trends Ecol Evol 33:310-312

* Tourinho J, Márquez A, Celentano E, Defeo O (2016) A new evolutionary unit in the Excirolana braziliensis species complex. Braz J Oceanogr 64:197-201

* Varela AI, Haye PA (2012) The marine brooder Excirolana braziliensis (Crustacea: Isopoda) is also a complex of cryptic species on the coast of Chile. Rev Chil Hist Nat 85:495-502

* Zúñiga-Reinoso A, Benítez HA (2015) The overrated use of the morphological cryptic species concept: an example with Nyctelia darkbeetles (Coleoptera: Tenebrionidae) using geometric morphometrics. Zool Anz 255:47-53

Submitted: June 9, 2018; Accepted: July 19, 2018

Proofs received from author(s): August 6, 2018 